KOŚCIÓŁ I PRAWO 9(22) 2020, nr 2, s. 23-36

DOI: http://dx.doi.org/10.18290/kip2092-2

\author{
Maciej Kiliszek
}

\title{
PRZENIKANIE SIĘ ZADAŃ DUSZPASTERSKICH \\ I EKONOMICZNYCH RAD PARAFIALNYCH \\ W WYPEŁNIANIU MISJI KOŚCIOŁA \\ W KONTEKŚCIE POLSKIEGO PRAWA \\ PARTYKULARNEGO
}

Ojcowie Soboru Watykańskiego II w konstytucji dogmatycznej o Kościele $^{1}$ wyraźnie określili prawa przynależne wiernym świeckim do otrzymywania zarówno dóbr duchowych od pasterzy Kościoła - czy to w sakramentach, czy w posłudze słowa Bożego - jak i obowiązek przedstawiania im swoich potrzeb oraz życzeń w tym zakresie (LG 37$)^{2}$. Świeccy mają możliwość (stosownie do kompetencji i zdolności), a czasem nawet moralny obowiązek, mając na celu pożytek wspólnoty, wyjawiać świętym pasterzom swoje zdanie dotyczące dobra Kościoła (LG 37; kan. 212 § 3). Ponadto najwyższy ustawodawca kodeksowy nakłada na nich obowiązek zaradzania potrzebom Kościoła, by mógł sprawować kult, dzieła apostolskie, posługę miłości (kan. $222 \S 1$ ). Laikat powinien starać się także o godziwe utrzy-

MACIEJ KILISZEK - Wydział Prawa Kanonicznego, Uniwersytet Kardynała Stefana Wyszyńskiego w Warszawie; e-mail: maciej.kiliszek@student.uksw.edu.pl; https:// orcid.org/0000-0002-3208-3870

${ }^{1}$ Sacrosanctum Concilium Oecumenicum Vaticanum II, Constitutio dogmatica de Ecclesia Lumen gentium (21.11.1964), AAS 57 (1965), s. 5-75 [dalej cyt.: LG]; tekst polski w: Sobór Watykański II, Konstytucje, dekrety, deklaracje, Pallottinum, Poznań 1986, s. 127-265.

${ }^{2}$ Zob. także Codex Iuris Canonici auctoritate Ioannis Pauli PP. II promulgatus (25.01.1983), AAS 75 (1983), pars II, s. 1-317; tekst polski: Kodeks Prawa Kanonicznego, przekład polski zatwierdzony przez Konferencję Episkopatu, Pallottinum, Poznań 1984 [dalej cyt.: KPK/83], kan. 212 § 2, kan. 213. 
manie świętych szafarzy i wspierać ubogich z własnych dochodów (kan. 222). Ojcowie soborowi zachęcili pasterzy Kościoła do wspierania i uznawania tej misji wiernych świeckich w Kościele. Ponadto polecili duchownym korzystanie z roztropnej rady świeckich, powierzanie im zadań w służbie Kościoła, pozostawianie im swobody i pola do działania, wspierania w ich inicjatywach, a także rozważanie przedsięwzięć, życzeń i pragnień przedstawianych im przez wiernych świeckich (LG 37; kan. 275 § 2). Wzajemna współpraca świeckich i duchownych ma za zadanie umacniać odpowiedzialność, zapał i siły apostolskie wiernych oraz przyczyniać się do celniejszego i skuteczniejszego pełnienia posłannictwa w świecie, zarówno w sprawach duchowych, jak i doczesnych (LG 37; kan. 210-211 i 216) ${ }^{3}$.

\section{RYS HISTORYCZNY - OD RAD W DIECEZJI DO RAD W PARAFII}

Ustawodawca w Kodeksie Prawa Kanonicznego z 1917 r. ${ }^{4}$ nie powołuje rad duszpasterskich, a zwłaszcza nie przewiduje tak aktywnej roli laikatu, jak czyni to ustawodawstwo od Soboru Watykańskiego II, opierające się na odnowionej wizji zadań świeckich w świecie ${ }^{5}$. Pierwsze normy wydane w tej materii znajdują się w liście apostolskim papieża Pawła VI Ecclesiae Sanctae (nr 15), w którym stanowi na temat sposobu działania rad duszpasterskich w diecezjach, w których zaczęto promować taki rodzaj dzia-

\footnotetext{
${ }^{3}$ Por. Sacrosanctum Concilium Oecumenicum Vaticanum II, Decretum de institutione sacerdotali Optatam totius (28.10.1965), AAS 58 (1966), s. 713-27 [dalej cyt.: OP]; tekst polski w: Sobór Watykański II, Konstytucje, s. 435-69; nr 19-20.

${ }^{4}$ Codex Iuris Canonici: Pii X Pontificis Maximi iussu digestus Benedicti Papae XV auctoritate promulgatus. Praefatione, fontium annotatione et indice analytico-alphabetico ab emo. Petro Gasparri auctus, red. Petro Gasparri, Typis Polyglottis Vaticanis, Romae 1918 [dalej cyt.: KPK/17]

${ }^{5}$ Dla przykładu warto podać kilka dokumentów, które promują aktywną rolę laikatu np.: Paulus PP. VI, Litterae apostolicae motu proprio datae Normae ad quaedam exsequenda SS. Concilii Vaticani II Decreta statuuntur Ecclesiae Sanctae (06.08.1966), AAS 58 (1966), s. 757-87 [dalej cyt.: ES]; tekst polski w: Ustrój hierarchiczny Kościoła. Wybór źródet, red. i oprac. W. Kacprzyk, M. Sitarz, Wydawnictwo KUL, Lublin 2006, s. 138-55; Sacrosanctum Concilium Oecumenicum Vaticanum II, Decretum de apostolatu laicorum Apostolicam actuositatem (18.11.1965), AAS 58 (1966), s. 837-64 [dalej cyt.: AA]; tekst polski w: Sobór Watykański II, Konstytucje, s. 563-672; Tenże, Decretum de pastorali episcoporum munere in Ecclesia Christus Dominus (28.10.1965), AAS 58 (1966), s. 673-701 [dalej cyt.: CD]; tekst polski w: Sobór Watykański II, Konstytucje, s. 341-99, nr 27.
} 
łalności w formie - jeszcze wtedy - eksperymentu i nieobligatoryjnie [Pawluk 1985, 74]. Następnie, po Synodzie Biskupów zebranym na sesji zwyczajnej w 1971 r., Kongregacja do Spraw Duchowieństwa poprosiła, aby Przewodniczący Konferencji Biskupich przesłali opinie i propozycje dotyczące działalności rad duszpasterskich, zarówno na podstawie własnych doświadczeń, jak i na podstawie norm wydawanych dla tych $\mathrm{rad}^{6}$. Kongregacja wydała 15 marca 1972 r. normy dotyczące organizacji diecezjalnych rad duszpasterskich, których struktura została zachowana w KPK/83 (OCh 1, 7-10).

Ustawodawca kodeksowy zachęca do powołania rad duszpasterskich w diecezjach, gdy biskup diecezjalny uzna, że tego wymagają racje duszpasterskie (kan. 511) ${ }^{7}$. Nadto najwyższy ustawodawca wskazuje na możliwość powołania takich rad duszpasterskich nie tylko w diecezji, ale także w parafii (kan. 536). KPK/83 rozszerza zakres działalności rad wprowadzonych w Ecclesiae Sanctae i zaleca organy doradcze już nie tylko

${ }^{6}$ Święta Kongregacja ds. Duchowieństwa, List okólny Omnes christifideles (25.01. 1973) [dalej cyt.: OCh], w: Posoborowe prawodawstwo kościelne, oprac. E. Sztafrowski, t. 7, z. 1, Akademia Teologii Katolickiej, Warszawa 1973, s. 231-49, nr 5.

${ }^{7}$ Należy zauważyć spór wśród kanonistów co do obowiązku ustanowienia rady duszpasterskiej w diecezji. Np. T. Pawluk podaje, że powołanie diecezjalnej rady duszpasterskiej „ma formę nakazu” [Pawluk 1985, 74-75]. J. Dyduch twierdzi, że powołanie tego organu „nie jest ściśle nakazane” [Dyduch 1984, 57-58, 61]. Z kolei J. Wroceński, że ,jednak użyte w tekście łacińskim słowo constituatur zawiera w sobie pewien charakter imperatywny. Aby lepiej oddać jego treść należy opowiedzieć się za większością autorów, że jeżeli potrzeby duszpasterskie diecezji wymagają powołania Diecezjalnej Rady Duszpasterskiej wówczas biskup jest zobowiązany ją ustanowić” [Wroceński 1991, 106]. Natomiast zgodnie z instrukcją Ecclesiae imago: „Chociaż Rada Duszpasterska nie jest nakazana, to jednak bardzo się ją zaleca”. Zob. Kongregacja ds. Biskupów, Instrukcja na temat pasterskiej posługi biskupów Ecclesiae imago (22.02.1973) [dalej cyt.: EI], w: Ustrój hierarchiczny Kościoła. Wybór źródet, s. 403-516, nr 204. Powołanie rady duszpasterskiej, w miarę możliwości, jest obowiązkiem biskupa na terenach misyjnych. Kongregacja ds. Duchowieństwa stwierdziła: „Obowiązujące ustawodawstwo kanoniczne pozostawia biskupowi diecezjalnemu ocenę dotyczącą erygowania w parafiach Parafialnej rady duszpasterskiej, co jednak można zwykle uznać za szczególnie zalecane, jak przypomniał nam papież Franciszek: «Jakże konieczne są rady duszpasterskie! Biskup nie może prowadzić diecezji bez rad duszpasterskich. Proboszcz nie może prowadzić parafii bez rady duszpasterskiej»". Zob. Kongregacja ds. Duchowieństwa, Instrukcja Nawrócenie duszpasterskie wspólnoty parafialnej w służbie misji ewangelizacyjnej Kościoła (20.07.2020) [dalej cyt.: Instrukcja], http://press.vatican.va/ content/salastampa/it/bollettino/pubblico/2020/07/20/0391/00886.html\#pol [dostęp: 17.10. 2020], nr 108. Por. Sacrosanctum Concilium Oecumenicum Vaticanum II, Decretum de activitate missionali Ecclesiae Ad gentes divinitus (07.12.1965), AAS 58 (1966), s. 94790 [dalej cyt.: AG]; tekst polski w: Sobór Watykański II, Konstytucje, s. 661-739, nr 30. 
w diecezji, ale także w parafii, zaznaczając, że zarówno diecezjalne, jak i parafialne rady duszpasterskie mają jedynie głos doradczy w sprawach dotyczących odpowiednio diecezji, jak i parafii (kan. 514, 536). W skład tych rad powinni wchodzić wierni świeccy (kan. 512, 536; OCh 7), aby przedstawiać pasterzom swoje potrzeby, pragnienia i praktyczne wnioski dotyczące duszpasterstwa, aby Boże przepowiadanie zbawienia rozszerzało się coraz bardziej (kan. 211, 212 § 2, 511; OCh 8-10).

Odmienną pozycję prawną w KPK/17 miały rady ekonomiczne. W tytule o administracji dóbr kościelnych ustawodawca wymieniał je jako organ doradczy biskupa, który biskup powinien był ustanowić (kan. 1520 § 1 i 3). Zdania tego organu biskup nie powinien był pomijać (kan. 1520 § 3). KPK/17 co do zasady powierzał administrację dobrami doczesnymi osobie duchownej. Należy jednak zauważyć, że za Soborem Trydenckim umożliwiał administrację dobrami kościelnymi nawet przez osobę świecką, która zdaniem ordynariusza miejsca była do tego kompetentna (kan. $1521 \S 2)^{8}$. Ordynariusz zawsze zachowywał prawo do wizytowania, wnioskowania o złożenie wyjaśnień co do motywów działania administratora dóbr oraz uprzedniego pisemnego opisu sposobu administracji dobrami ${ }^{9}$. Ponadto na podstawie KPK/17 ordynariusz lub jego delegat mógł fakultatywnie powołać radę fabricae ecclesiae (kan. 1183) [Lewicka i Sitarz 2019, 2076].

Zgodnie z KPK/83 zarówno diecezjalna, jak i parafialna rada ekonomiczna powinny zostać ustanowione. Rządzą się one przepisami prawa powszechnego oraz normami wydanymi przez biskupa diecezjalnego (kan. 492, 537) [tamże, 2076-2077].

Niezwykle wyraźnie widać poszerzenie kompetencji świeckich na polu uczestnictwa w radach ekonomicznych, niejako w duchu Soboru Watykańskiego II, w uprawnieniach zastępców ekonomów diecezjalnych w dokumentach wydanych dla katolickich Kościołów wschodnich. Uprawnienia

\footnotetext{
${ }^{8}$ Sobór Vienneński, Dekret Quia contingit, w: Dokumenty Soborów Powszechnych. Tekst grecki, taciński, polski. T. II (869-1312). Konstantynopol IV. Lateran I. Lateran II. Lateran III. Lateran IV. Lyon I. Lyon II. Vienne, układ i oprac. A. Baron, H. Pietras, Wydawnictwo WAM. Księża Jezuici, Kraków 2003, s. 570-73; Concilium Tridentinum, Sess. VII, de ref., c. 15, w: Dokumenty Soborów Powszechnych. Tekst taciński, polski. T. IV (1511-1870). Lateran V, Trydent, Watykan I, układ i oprac. A. Baron, H. Pietras, Wydawnictwo WAM. Księża Jezuici, Kraków 2007, s. 374-75; Tenże, Sess. XXV, de ref., c. 8, w: Dokumenty Soborów Powszechnych. Tekst taciński, polski. T. IV (1511-1870), s. $822-25$.

${ }^{9}$ Kan. 1521 § $2 \mathrm{KPK} / 17$ in fine: „ac salvo iure Ordinarii visitandi, exigendi rationes et praescribendi modum administrationis”.
} 
zawarte $\mathrm{w}$ listach apostolskich papieża Piusa XII: Postquam apostolicis oraz Cleri sanctitati są bardzo zbliżone do współczesnej formy ekonomicznej rady diecezjalnej ${ }^{10}$. Należy zwrócić uwagę, że w tych częściowych kodyfikacjach dla katolickich Kościołów wschodnich nie istniała jeszcze instytucja ekonomicznej rady parafialnej, której istnienie obecnie jest obligatoryjne zgodnie z kan. 295 Kodeksu Kanonów Kościołów Wschodnich ${ }^{11}$. Jednak Kodeks ten nie reguluje udziału świeckich w takiej radzie, a jedynie pozostawia tę kwestię prawu partykularnemu Kościoła sui iuris.

Warto podkreślić, że przed Soborem Watykańskim II prawo powszechne kładło nacisk na istnienie rad $\mathrm{w}$ diecezjach, a dopiero odczytana na nowo soborowa eklezjologia stała się impulsem do erygowania rad w parafiach, tworzonych często na wzór rad diecezjalnych.

\section{DUSZPASTERSKA RADA PARAFIALNA}

Powołanie organu doradczego ma za zadanie pomóc podjąć jak najlepszą decyzję przełożonemu kościelnemu [Krukowski 2005, 446; Domaszk 2016; 192-93, Lewicka i Sitarz 2019, 2074-2075]. W niektórych sprawach poza głosem rady ekonomicznej, przydatny mógłby być głos rady duszpasterskiej [Sánchez-Gil 2002, 1295; Domaszk 2016, 194]. Erygowanie tych rad w warunkach parafialnych jest wymogiem nowo odczytanej eklezjologii Soboru Watykańskiego II, który podkreśla wkład wiernych w odpowiedzialność za wspólnotę Kościoła na szczeblu lokalnym przez odnawianie porządku doczesnego, aby w ten sposób troszczyć się o potrzeby całego Ludu Bożego (LG 30, 38; AG 21; AA 5-8, 10) ${ }^{12}$. To szczególne zadanie wierni realizują we własnych wspólnotach parafialnych przez działanie

${ }^{10}$ Pius PP. XII, Motu proprio de religiosis, de bonis ecclesiae temporalibus et de verborum significatione pro ecclesiis orientalibus Postquam apostolicis (09.02.1952), AAS 44 (1952), s. 65-152, kan. $262 \S 2$, 2º; Tenże, Litterae apostolicae motu proprio datae de ritibus orientalibus, de personis pro ecclesiis orientalibus Cleri sanctitate (02.06.1957), AAS 49 (1957), s. 433-603, kan. 299, $438 \S 2,2^{\circ}$.

${ }^{11}$ Codex Canonum Ecclesiarum Orientalium auctoritate Ioannis Pauli PP. II promulgatus (18.10.1990), AAS 82 (1990), s. 1045-363; tekst polski: Kodeks Kanonów Kościołów Wschodnich promulgowany przez papieża Jana Pawła II, tłum. L. Adamowicz, M. Dyjakowska, Wydawnictwo Archidiecezji Lubelskiej Gaudium, Lublin 2002.

${ }^{12}$ Por. Sacrosanctum Concilium Oecumenicum Vaticanum II, Decretum de presbyterorum ministerio et vita Presbyterorum ordinis (07.12.1965), AAS 58 (1966), s. 9911024; tekst polski w: Sobór Watykański II, Konstytucje, s. 741-809, nr 9. 
w organach doradczych proboszcza: duszpasterskiej radzie parafialnej oraz ekonomicznej radzie parafialnej. Jest to ich szczególne prawo, ale też i obowiązek (LG 37; kan. 212, 228), który w adhortacji apostolskiej Christifideles laici wyraził papież Jan Paweł II w słowach: „Świeccy winni nabierać coraz głębszego przekonania o tym, jak bardzo istotne jest apostolskie zaangażowanie na terenie własnej parafii”"13. Ich szczególne działanie $\mathrm{w}$ obrębie parafii jest realizacją wzrostu doskonałej komunii z Kościołem powszechnym (AA 10).

Ustawodawca $\mathrm{w}$ KPK/83 podaje, że wskazane jest erygowanie parafialnej rady duszpasterskiej (kan. 536) ${ }^{14}$. Ustanowienie takiej rady uzależnione jest od oceny biskupa diecezjalnego, który po zasięgnięciu opinii rady kapłańskiej może nakazać utworzenie takich rad w każdej parafii na terenie diecezji. Taka konstrukcja wskazuje na częściowo fakultatywny charakter istnienia tego ciała doradczego, na obligatoryjny zaś tam, gdzie tak stanowi prawo partykularne (Instrukcja 108) [Pavanello 2009, 485; Lewicka i Sitarz 2019, 2078].

Prawo powszechne nadaje parafialnej radzie duszpasterskiej jedynie głos doradczy, a szczegółowe normy dotyczące działalności tego organu zleca wydać biskupowi diecezjalnemu [Calvo 2011a, 462-63]. Członkowie tej rady, analogicznie do diecezjalnej rady duszpasterskiej, powinni pozostawać w pełnej wspólnocie z Kościołem katolickim, odznaczać się pewną wiarą, dobrymi obyczajami i roztropnością, a także być dobrani tak, żeby skład rady był rzeczywistym odzwierciedleniem struktury społecznej stanowiącej parafię. Jeśli to możliwe rada powinna składać się zarówno z duchownych, jak i członków instytutów życia konsekrowanego, a przede wszystkim ze świeckich. Powinna być rzeczywistym odzwierciedleniem struktury społecznej parafii i uwzględniać warunki społeczne, zawodowe

\footnotetext{
${ }^{13}$ Ioannes Paulus PP. II, Adhortatio apostolica post-synodalis de vocatione et missione laicorum in ecclesia et in mundo Christifideles laici (30.12.1988), AAS 81 (1989), s. 393-521 [dalej cyt.: ChL], nr 26.

${ }^{14}$ Warto wskazać nakaz powoływania takich rad w instrukcji Ecclesiae imago (nr 179), natomiast w dyrektorium Apostolorum Succesores już tylko wyraźną zachętę do powoływania takich rad: Congregazione per i Vescovi, Direttorio per il ministero pastorale dei vescovi Apostolorum Successores (22.02.2004) [dalej cyt.: AS], w: Ustrój hierarchiczny Kościoła. Wybór źródet, s. 517-711, nr 211. Zob. II Polski Synod Plenarny (1991-1999), Pallottinum, Poznań 2001 [dalej cyt.: IIPSP], nr 23 [Calvo 2011a, 462-63].
} 
oraz udział, jaki osoby mają w apostolstwie (kan. $512 \S 2)^{15}$. Rada duszpasterska powinna działać pod przewodnictwem proboszcza i starać się pomagać mu w realizacji potrzeb duszpasterskich parafian (kan. 514) tak, aby nieść skuteczną pomoc proboszczowi na polu uświęcania dusz [Wroceński 2013, 124]. W skład rady - poza proboszczem należącym do rady ze względu na pełniony urząd - wchodzą także ci, którzy z racji pełnionych innych urzędów uczestniczą w trosce duszpasterskiej o parafię (np. wikariusze parafialni, diakoni), a zwłaszcza powinni to być wierni świeccy ${ }^{16}$.

Prawo powszechne nie stanowi na temat kadencji rad czy ich ewentualnego ustania (czy to przez decyzję kompetentnej władzy kościelnej, czy przez wakat na urzędzie proboszcza lub biskupa), jak też na temat częstotliwości spotkań rady. Jeśli prawo partykularne nie reguluje parafialnych rad duszpasterskich w tym zakresie, wydaje się słuszne stosować per analogiam przepisy odnośnie do diecezjalnych rad duszpasterskich (kan. 511-514; OCh 7) [Dyduch 1984, 62].

Istnienie duszpasterskiej rady parafialnej jest o tyle istotne $\mathrm{w}$ realizacji misji Kościoła, o ile spełniać będzie ona swoje podstawowe zadania, które wyznacza jej natura i cel Kościoła. Zadaniami duszpasterskiej rady parafialnej są te, które najwyższy prawodawca zlecił diecezjalnym radom duszpasterskim, w stopniu odpowiednim do potrzeb i charakteru wspólnoty parafialnej [Wroceński 2013, 114]. Zadania te, to przede wszystkim doradzanie proboszczowi w sposobie doboru środków duszpasterskich, a także wskazanie potrzeb wspólnoty wiernych. Nie jest to organ, który miałby wyręczać proboszcza w kierowaniu parafią i ograniczać jego przewodnią rolę pasterza (NMI 45; OCh 3,8$)^{17}$. Na wzór rady diecezjalnej rada duszpasterska powinna brać pod uwagę to, co dotyczy działalności duszpasterskiej, a także rozwijać praktyczne wnioski i pogłębiać świadomość religijną oraz zgodność życia Ludu Bożego z Ewangelią (kan. 511; OCh 9) [Wroceński 2013, 122; Tenże 1991, 107].

\footnotetext{
${ }^{15}$ Ioannes Paulus PP. II, Epistula apostolica episcopis clero fidelibus magni iubilaei anni MM sub exitum Novo millennio ineunte (06.01.2001), AAS 93 (2001), s. 266-309 [dalej cyt.: NMI], nr 45. Zob. Wroceński 2013, 119.

${ }^{16}$ Paulus PP. VI, Litterae apostolicae motu proprio datae Sacrum diaconatus ordinem generales normae de diaconatu permanenti in Ecclesia latina restituendo feruntur (18.06.1967), AAS 59 (1967), s. 697-704, nr 24. Zob. Pavanello 2009, 485-86; Lewicka i Sitarz 2019, 2078.

${ }^{17}$ Kongregacja ds. Duchowieństwa, Instrukcja Kapłan, pasterz i przewodnik wspólnoty parafialnej, Wrocławska Księgarnia Archidiecezjalna, Wrocław 2002, nr 26. Zob. Wroceński 2013, 115.
} 
Rada duszpasterska może być dobrą formą przedyskutowania planu duszpasterskiego, różnych inicjatyw misyjnych, katechetycznych i apostolskich. Może ona podjąć tematy środków służących pogłębienia formacji doktrynalnej, życia sakramentalnego wiernych, a także dzieł posługi ubogim i potrzebującym w ramach diakonii na rzecz osób biednych i potrzebujących, by być „domem otwartym dla wszystkich i gotowym służyć każdemu" (ChL 27) [tamże].

Ten wyjątkowy charakter służby na rzecz bliźniego opisuje dekret o apostolstwie świeckich, który wskazuje, że istotnym elementem apostolstwa jest odpowiednia formacja (AA 28-32). Zaczyna się ona w Kościele domowym przez wychowanie dzieci, realizuje się we wspólnocie parafialnej, rozbudzana jest wśród młodzieży przez angażowanie się w ruchy i stowarzyszenia wiernych, by realizować misję Kościoła zgodnie z własnymi zdolnościami, powołaniem i talentami, którymi Bóg dał wierzącym dla dobra braci w wierze (AA 30). Ojcowie soborowi podkreślają wyjątkową pozycję uczynków miłości i miłosierdzia $\mathrm{w}$ świadectwie życia chrześcijańskiego, które winno tak być kształtowane, by wierni „nauczyli się od dzieciństwa współczuć braciom i wspaniałomyślnie wspomagać potrzebujących". Podobne zadanie stawia przed osobami formującymi alumnów seminariów duchownych dekret o formacji kapłańskiej, wskazując, że tak należy kształtować alumnów, by jasno ukazać, że działalność charytatywna jest jednym ze sposobów realizacji świętej posługi (OP 19; por. kan. 282 §). To wyjątkowe zadanie chrześcijan do niesienia pomocy potrzebującym, którego świadectwo mamy w Piśmie Świętym (Dz 2,45; Dz 4,34-35; Ga 2,10) jest tak istotne w życiu Kościoła, że jest jednym z wezwań, które zaleca się w strukturze modlitwy powszechnej ${ }^{18}$. To zadanie wyrażają słowa papieża Grzegorza: „w świętym Kościele każdy wspiera wszystkich i wszyscy są wsparciem każdego" (ChL 28).

\section{EKONOMICZNA RADA PARAFIALNA}

Oprócz duszpasterskich rad parafialnych, należy powołać w parafii ekonomiczną radę parafialną. Ustawodawca powszechny wyraźnie wskazuje,

\footnotetext{
${ }^{18}$ Institutio generalis Missalis Romani, nr 70; Missale Romanum ex decreto Sacrosancti Oecumenici Concilii Vaticani II renovatum auctoritate Pauli PP VI. editum Ioannis Pauli PP. II cura recognitum, Libreria Editrice Vaticana, Città del Vaticano 2008, s. 34-35; Modlitwa powszechna, vademecumliturgiczne.pl/2016/08/19/modlitwapowszechna [dostęp: 23.09.2020].
} 
że istnienie ekonomicznej rady parafialnej jest obligatoryjne, natomiast powołanie duszpasterskiej rady w parafii jest wymagane, gdyby było to pożyteczne zdaniem biskupa diecezjalnego (kan. 536-537; por. AS 211; IIPSP 23) [Krukowski 2005, 446-47; Calvo 2011a, 462-63; Tenże 2011b, 463; Wroceński 2013, 117, 124]. Kan. 537 KPK/83 jest uszczegółowieniem ogólnej zasady kan. $1280 \mathrm{KPK} / 17$, który nakazuje każdej osobie prawnej, którą parafia jest na podstawie Kodeksu, posiadanie rady ds. ekonomicznych (kan. 515 § 3, 537, 1280) [Sánchez-Gil 2002, 1293-294; Krukowski 2005, 446-47; Wroceński 2013, 124-25; Lewicka i Sitarz 2019, 2076-2077].

Prawa i obowiązki, zadania i skład ekonomicznej rady parafialnej mogą rządzić się przepisami trojakiego źródła. Pierwszym jest prawo powszechne (w oparciu o analogię do ekonomicznych $\operatorname{rad} \mathrm{w}$ diecezji); drugim jest prawo partykularne [Sánchez-Gil 2002, 1295], zwłaszcza ustanawiane przez biskupów na synodach lub dekretami wykonawczymi biskupa ${ }^{19}$; a trzecim może być zwyczaj dotyczący funkcjonowania rad w Kościele partykularnym ${ }^{20}$, o ile nie jest sprzeczny z ustawodawstwem powszechnym.

Zależnie od prawa partykularnego, skład parafialnej rady ekonomicznej może być różny. Wskazuje się, że rada powinna być nie za duża, ale powinna składać się z przynajmniej trzech członków mianowanych swobodnie przez proboszcza, który może posłużyć się przy tym konsultacją wśród parafian (por. Instrukcja 102-103) ${ }^{21}$. Członkowie rad ekonomicznych powinni odznaczać się dobrą opinią, roztropnością, bezinteresownością i poczuciem odpowiedzialności [Krukowski 2005, 447; Wroceński 2013, 126; Lewicka i Sitarz 2019, 2077]. Kandydaci powinni posiadać kompetencje i przymioty, które pozwolą należycie wypełniać ich posługę w radzie lub działaniu w zakresie kompetencji udzielonych radzie przez proboszcza. Przymiotami tymi powinna być szczególna biegłość i znajomość w sprawach gospodarczych, ekonomicznych i prawno-administracyjnych, wiedza i doświadczenie, oddanie sprawom Kościoła, a także znajomość V Księgi KPK/83

\footnotetext{
${ }^{19}$ Choć należy zauważyć, że proboszcz ma obowiązek na podstawie KPK/83 powołać ekonomiczną radę parafialną, a nie ma on potrzeby czekać na takowy dekret biskupa [Krukowski 2005, 446-47; Wroceński 2013, 125-26].

${ }^{20}$ Zdarza się, że synody diecezjalne normują istniejące już zwyczaje dotyczące prawa partykularnego. Por. Synod Archidiecezji Przemyskiej 1995-2000: statuty i aneksy, Wydawnictwo Archidiecezji Przemyskiej, Przemyśl 2000, stat. 53 § 2; Synod Archidiecezji Wrocławskiej: 1985-1991, Kuria Metropolitalna Wrocławska, Wrocław 1995, nr 33.

${ }^{21}$ Analogicznie do nominacji w kan. 942 § 1 KPK/83 [Sánchez-Gil 2002, 1294].
} 
„Dobra doczesne Kościoła”22. Wymogiem stawianym przed kandydatem jest też bycie wiernym chrześcijaninem, a więc ochrzczonym wierzącym (czy to świeckim, czy to duchownym), pozostającym we wspólnocie z Kościołem katolickim (kan. 204, 537) [Krukowski 2005, 447; Wroceński 2013, 126].

Do głównych zadań ekonomicznej rady parafialnej należy troska o względy gospodarcze $\mathrm{w}$ parafii dotyczące rady w sferze majątkowej czy finansowej, ocena inicjatyw, projektów ekonomicznych i zadań remontowo-budowlanych, pomoc przy zbieraniu funduszy na cele parafialne [Sánchez-Gil 2002, 1294-295; Wroceński 2013, 129-30]. Może ona także informować ogół wiernych o dochodach parafii i sposobach ich spożytkowania [IIPSP 79]. Rada może opiniować stawki i warunki pracy osób zatrudnionych przy funkcjonowaniu parafii (zakrystianin, kościelny, organista, pracownicy remontowo-budowlani itp.) [Wroceński 2013, 129-30]. Należy zwrócić uwagę, że jest to wyłącznie organ doradczy i tak samo jak w przypadku parafialnej rady duszpasterskiej, proboszcz nie ma obowiązku iść za radą parafian. Proboszcz powinien rozważyć opinię rady (choć wysłuchanie rady nie jest wymagane do ważnego podjęcia aktu), a w przypadku podjęcia działania innego od zdania rady, powinien przedstawić radzie swoje racje [Sánchez-Gil 2002, 1295; Krukowski 2005, 446-47; Calvo 2011b, 463; Wroceński 2013, 130-31].

Warto zwrócić uwagę na zadanie ekonomicznych rad parafialnych w sytuacji zmiany proboszcza bądź w sytuacji nadzwyczajnej. Biskup diecezjalny może ustanowić prawo zobowiązujące członków rady do zabezpieczenia majątku kościelnego i beneficjalnego, by dobra parafialne nie doznały uszczerbku. Członkowie rady mogą być obecni przy spisywaniu protokołu zdawczo-odbiorczego przy przekazywaniu nowo mianowanemu proboszczowi lub administratorowi zarządu nad parafią [tamże, 129]. Nadzwyczajną sytuacją, w której wskazana byłaby pomoc członków rady, mogłaby być sytuacja losowa, np. powódź, pożar, kradzież, w czasie nieobecności proboszcza [tamże, 130]. Członkowie parafialnych rad ekonomicznych mogą nieść nieocenioną pomoc w parafiach, w których w razie śmierci proboszcza nie byłoby osoby z urzędu odpowiedzialnej za administrację i strzeżenie majątku parafialnego, do czasu zamianowania administratora [tamże].

${ }^{22}$ Analogicznie do przymiotów osób, o których w kan. 942 § 1 i kompetencji z kan. 493 [Sánchez-Gil 2002, 1294; Wroceński 2013, 126; Lewicka i Sitarz 2019, 2077]. 
Przenikanie się zadań duszpasterskich i ekonomicznych rad parafialnych 33

\section{4. ŁĄCZENIE ZADAŃ}

Sposób działania duszpasterskich i ekonomicznych rad parafialnych opisują badania empiryczne prowadzone przez socjologów i teologów pastoralistów. W niektórych diecezjach lub parafiach nie ma lub nie działają właściwie rady ekonomiczne [Rojowski 2016, 61-62]. Duszpasterskie rady parafialne często wchodzą $\mathrm{w}$ kompetencje ekonomicznych rad parafialnych zarówno w zakresie doradzania, jak i działania [Wielebski 2015, 276]. Duszpasterskie rady parafialne w Polsce w 27\% swoich porad odnoszą się do inicjatyw charytatywnych, a tylko w $16 \%$ do inicjatyw apostolskich [Sadłoń 2013, 88; Wielebski 2015, 275-76]. Ponadto duszpasterskie rady parafialne podejmują działania co do inwestycji (26\%), działalności charytatywnej (13\%), administracyjnej (12\%) i gospodarczej (11\%), a wydawać by się mogło, że działalność duszpastersko-apostolska (26\%) jest w niej względem innych działań zaniedbywana [Sadłoń 2013, 89]. W literaturze podkreśla się, że działalność charytatywna Kościoła jest istotnym, aczkolwiek nie jedynym polem działania Kościoła [Wielebski 2015, 281].

Wzajemne skoordynowanie oraz uporządkowanie działań analizowanych rad może przyczynić się do owocniejszej służby na rzecz Kościoła partykularnego. Zacieśnienie współpracy, przynależność członków do rad, może wiele wnieść na polu duszpasterskim, ale należy uważać, żeby nie zatracić celów oraz sposobów działania rad i nie „zlać” dwóch organizmów w jeden [Dyduch 1984, 74-76]. Należy zauważyć, że analogiczna sytuacja jest na polu parafialnym: właściwa współpraca wiernych z proboszczem wymaga „najpierw dojrzałej wspólnoty parafialnej, w której istnieje możliwość (!) powołania rady ekonomicznej" [Zagrodzki 2004, 110], a następnie podejmowania przez wiernych działań, również na polu odpowiedzialności materialnej za wspólnotę, które są skutkiem chrześcijańskiej formacji.

Ważnym postulatem działalności rad parafialnych może być formacja parafii. „Trzeba jednak zacząć od formacji środowiska parafialnego, w którym rada ekonomiczna mogłaby pozytywnie zaistnieć” [tamże, 113]. W takim modelu duszpasterstwa parafialnego zorganizowane są rady w niektórych diecezjach. Ustanawiają one $\mathrm{w}$ parafii jedną radę duszpasterską, która wypełnia również zadania rad ekonomicznych ${ }^{23}$. Zdarza się, że sta-

${ }^{23}$ Synod Archidiecezji Przemyskiej, stat. 53 § 2; Synod Archidiecezji Wrocławskiej, nr 424-431; Statut Rad Duszpasterskich Archidiecezji Lubelskiej, http://pliki.diecezja. lublin. pl/prawo/prawo_diecezjalne/statut_i_wybory_rad_parafialnych.html [dostęp: 17.02.2021], 
tuty parafialnych rad duszpasterskich powierzają troskę o utrzymanie pracowników parafialnych lub podejmowanie działalności charytatywnej sobie samym ${ }^{24}$. Należy zauważyć, że tworzenie jednej rady duszpasterskoekonomicznej jest sprzeczne z wolą ustawodawcy, który w kan. 536-537 KPK/83 rozróżnia parafialną radę ekonomiczną od parafialnej rady duszpasterskiej. Rozwiązaniem pozwalającym zharmonizować działanie rad może być regulacja, która zezwala parafialnej radzie duszpasterskiej na wyrażenie opinii w sprawach ekonomicznych i przedłożenia jej radzie ekonomicznej ${ }^{25}$ lub zalecenie, by w kwestiach majątkowych odbywać wspólne posiedzenia parafialnych rad duszpasterskich i parafialnych rad ekonomicznych $^{26}$, a nawet udzielanie rady przewodniczącemu w kwestii składu parafialnej rady ekonomicznej ${ }^{27}$.

\section{PIŚMIENNICTWO}

Calvo, Juan. 2011a. „Komentarz do kan. 536.” W Codex Iuris Canonici. Kodeks Prawa Kanonicznego. Komentarz. Powszechne i partykularne ustawodawstwo Kościoła katolickiego. Podstawowe akty polskiego prawa wyznaniowego. Edycja polska na podstawie wydania hiszpańskiego, red. Piotr Majer, 462-63. Kraków: Wolters Kluwer Polska.

pkt 1; Statut Rad Duszpastersko-Ekonomicznych w Diecezji Zamojsko-Lubaczowskiej, https://diecezja.zamojskolubaczowska.pl/content/files/c30ded44dee088bd7ed

4022e8b91fa02_statut_i_regulamin_wyborow.pdf [dostęp: 17.02.2021]; Statut Parafialnej Rady Duszpasterskiej diecezji gliwickiej, www.opatowice.pl/dokumenty/statut _rady_duszp.pdf [dostęp: 17.02.2021], pkt 10. Zob. Wroceński 2013, 130-31.

${ }^{24}$ Statut Parafialnych Rad Duszpasterskich w Diecezji Rzeszowskiej, http://parafia wielopole.r-ce.pl/?page_id=449 [dostęp: 17.02.2021], pkt 2; Statuty I Synodu Diecezji Opolskiej, https://www.diecezja.opole.pl/index.php/component/content/category/31-ogolnodiecezjalne [dostęp: 16.02.2021], stat. 393; Statut Parafialnej Rady Duszpasterskiej $w$ Archidiecezji Katowickiej, https://www.barbarachorzow.katowice.opoka.org.pl/pdf/ R1.pdf [dostęp: 17.02.2021], pkt 2; Statut Parafialnej Rady Duszpasterskiej w Archidiecezji Czestochowskiej, https://archiczest.pl/dokumenty,18/ [dostęp: 17.02.2021], pkt 2.

${ }^{25}$ Statut Parafialnej Rady Duszpasterskiej (PRD) w Archidiecezji Gnieźnieńskiej, http://parafiadalki.pl/pl/rada-duszpasterska-i-rada-ekonomiczna [dostęp: 17.02.2021], pkt III.3; Statut Parafialnej Rady Duszpasterskiej Diecezji Elblaskiej, https://diecezja.elblag. pl/assets/PRAWO-DIECEZJALNE-DOKUMENTY/Statut-Parafialnej-Rady-Duszpaster skiej-2020.doc [dostęp: 17.02.2021], § 7; Statut Parafialnej Rady Duszpasterskiej w Diecezji Siedleckiej, https://www.parafiagarwolin.pl/userfiles/file/Statut\%20Parafialnej\%20 Rady\%20Duszpasterskiej\%20w\%20Diecezji\%20Siedleckiej.pdf [dostęp: 17.02. 2021], § 5.

${ }^{26}$ Statut Parafialnej Rady Duszpasterskiej Diecezji Etckiej"; http://pruska.diecezja. elk.pl/rada-parafialna.html [dostęp: 17.02.2021], pkt 15.

${ }^{27}$ IV Synod Archidiecezji Warszawskiej, Wydawnictwo Archidiecezji Warszawskiej, Warszawa 2003, nr 122 podaje: „Członków Rady wybiera proboszcz według własnego rozeznania, ale po konsultacji z Parafialną Radą Duszpasterską". 
Przenikanie się zadań duszpasterskich i ekonomicznych rad parafialnych 35

Calvo, Juan. 2011b. „Komentarz do kan. 537.” W Codex Iuris Canonici. Kodeks Prawa Kanonicznego. Komentarz. Powszechne i partykularne ustawodawstwo Kościoła katolickiego. Podstawowe akty polskiego prawa wyznaniowego. Edycja polska na podstawie wydania hiszpańskiego, red. Piotr Majer, 463. Kraków: Wolters Kluwer Polska.

Domaszk, Arkadiusz. 2016. Dobra doczesne Kościoła. Warszawa: Wydawnictwo Naukowe UKSW.

Dyduch, Jan. 1984 „Diecezjalna Rada Duszpasterska i Rada Kapłańska: (wzajemne relacje)." Prawo Kanoniczne 27, nr 3-4:53-76.

Krukowski, Józef. 2005. „Parafie, proboszczowie i wikariusze parafialni.” W Komentarz do Kodeksu Prawa Kanonicznego. T. II/1: Księga II. Lud Boży. Część I. Wierni chrześcijanie. Część II. Ustrój hierarchiczny Kościoła, red. Józef Krukowski, 409-63. Poznań: Pallottinum.

Lewicka, Mariola, i Mirosław Sitarz. 2019. „Parafialne rady.” W Leksykon Prawa Kanonicznego, red. Mirosław Sitarz, 2074-2079. Lublin: Stowarzyszenie Absolwentów i Przyjaciół Wydziału Prawa Katolickiego Uniwersytetu Lubelskiego.

Pavanello, Pierantonio. 2009. „Komentarz do kan. 536.” W Codice di dirito canonico commentato, 485-86. Milano: Àncora Editrice.

Pawluk, Tadeusz. 1985. „Diecezjalna rada duszpasterska w świetle nowego Kodeksu Prawa Kanonicznego.” Prawo Kanoniczne 28, nr 1-2:73-84.

Rojowski, Leszek. 2016. „Czy parafialne rady duszpasterskie w Polsce są rzeczywiście duszpasterskie?" Teologia Praktyczna 16:61-75.

Sadłoń, Wojciech. 2013. „Duszpasterskie rady parafialne w Polsce na podstawie badań empirycznych." Teologia Praktyczna 14:73-90.

Sánchez-Gil, Antonio S. 2002. „Comentario al can. 537.” W Comentario exegético al código de Derecho Canónico, t. 2, red. Ángel Marzoa Rodríguez, Jorge Miras, i Rafael Rodríguez-Ocaña, 1293-295. Pamplona: Eunsa Ediciones Universidad de Navarra.

Wielebski, Tomasz. 2015. „Parafialne rady duszpasterskie w Polsce w służbie budowania communio Kościoła.” Ateneum kapłańskie 165, z. 2 (639):262-84.

Wroceński, Józef. 1991 „Diecezjalna Rada Duszpasterska w nowym Kodeksie Prawa Kanonicznego." Prawo Kanoniczne 34, nr 3-4:105-13.

Wroceński, Józef. 2013. „Rady parafialne.” W Parafia $w$ prawie kanonicznym i prawie polskim, red. Sławoj L. Głódź, Józef Krukowski, i Mirosław Sitarz, 103-32. Lublin: Towarzystwo Naukowe KUL.

Zagrodzki, Wojciech. 2004. „Rada ekonomiczna.” Przeglad teologiczno-duszpasterski: Homo Dei 273, nr 4:109-14.

\section{Przenikanie się zadań duszpasterskich i ekonomicznych rad parafialnych w wypełnianiu misji Kościoła w kontekście polskiego prawa partykularnego}

\section{Streszczenie}

Rady parafialne są środkami realizacji apostolstwa świeckich w świecie i podejmowania przez nich odpowiedzialności za wspólnotę Kościoła. Kwestie ekonomiczne i duszpasterskie są ściśle ze sobą połączone. Wynika to z obowiązku wiernych do przepajania świata duchem Ewangelii. W związku z tym prawny obowiązek powoływania dwóch oddzielnych rad często nie spotyka się z faktyczną realizacją. Rady, mimo prawnego erygowania, mogą nie działać należycie. Powołanie rady ekonomicznej, która nie będzie współgrać z celami duszpasterskimi Kościoła, mogłoby podważyć sensowność 
działania takiej rady. Natomiast działalność rady duszpasterskiej, która zajmowałaby się przede wszystkim stanem ekonomicznym parafii, byłaby $\mathrm{w}$ sprzeczności $\mathrm{z}$ celem działania Kościoła. Należy zwrócić uwagę, że działalność świeckich w zakresie administracji dóbr doczesnych Kościoła, aktywność charytatywna i misyjna są istotnymi elementami dojrzałej formacji chrześcijańskiej, która wymaga podejmowania współodpowiedzialności zarówno za wspólnotę lokalną, Kościół misyjny, ale też za osoby odpowiedzialne za sprawowanie kultu i troskę nad miejscami świętymi.

Słowa kluczowe: parafialna rada duszpasterska; parafialna rada ekonomiczna; łączenie zadań; misja świeckich w świecie; troska o Kościół

\section{The Permeating of Pastoral and Finance Council Tasks to Fulfill the Ecclesiastical Purposes in the Context of Polish Particular Law}

\section{Summary}

The parish councils support the implementation of the lay apostolate in the world. They take responsibility for the community of the Church. The pastoral and finance issues are closely linked with one another. This arises from the obligation of the Christian faithful to permeate the world with the spirit of the Gospel. Therefore, the legal process of establishing two separate councils often does not meet with actual implementation. Even though they were establish legitimately, they may not function properly. The parish finance council that will not be in harmony with the pastoral goals of the Church could undermine the rationality of a council as such. Whereas the activity of the pastoral council, which would deal primarily with the economic state of the parish would be contrary to law. It should be noted that the activity of the laity in the administration of the ecclesiastical goods, charitable and missionary activity are significant components of the Christian maturity. It requires responsibility for the local community, the missionary Church, but also for people responsible for worship and caring for the sacred places.

Key words: parish pastoral council; parish finance council; grouping tasks; mission of the laity in the world; care for the Church

Information about Author: MACIEJ KILISZEK - Faculty of Canon Law, the Cardinal Stefan Wyszyński University in Warsaw; e-mail: maciej.kiliszek@student. uksw.edu.pl; https:// orcid.org/0000-0002-3208-3870 